Borders and Mobility in South Asia and Beyond 


\section{Asian Borderlands}

Asian Borderlands presents the latest research on borderlands in Asia as well as on the borderlands of Asia - the regions linking Asia with Africa, Europe and Oceania. Its approach is broad: it covers the entire range of the social sciences and humanities. The series explores the social, cultural, geographic, economic and historical dimensions of border-making by states, local communities and flows of goods, people and ideas. It considers territorial borderlands at various scales (national as well as supra- and sub-national) and in various forms (land borders, maritime borders), but also presents research on social borderlands resulting from border-making that may not be territorially fixed, for example linguistic or diasporic communities.

Series Editors

Tina Harris, University of Amsterdam

Willem van Schendel, University of Amsterdam

Editorial Board Members

Franck Billé, University of California, Berkeley

Duncan McDuie-Ra, University of New South Wales

Eric Tagliacozzo, Cornell University

Yuk Wah Chan, City University Hong Kong 


\title{
Borders and Mobility in South Asia and Beyond
}

\author{
Edited by \\ Reece Jones and Md. Azmeary Ferdoush
}


Cover illustration: Asad Zaman

Cover design: Coördesign, Leiden

Lay-out: Crius Group, Hulshout

$\begin{array}{ll}\text { ISBN } & 9789462984547 \\ \text { e-ISBN } & 9789048535224 \text { (pdf) } \\ \text { DOI } & 10.5117 / 9789462984547 \\ \text { NUR } & 761\end{array}$

(c) $(1) \Theta$

Creative Commons License CC BY NC ND (http://creativecommons.org/licenses/by-nc-nd/3.o)

@ The authors / Amsterdam University Press B.V., Amsterdam 2018

Some rights reserved. Without limiting the rights under copyright reserved above, any part of this book may be reproduced, stored in or introduced into a retrieval system, or transmitted, in any form or by any means (electronic, mechanical, photocopying, recording or otherwise). 